\title{
The Influence of Certain Trace Metals on Bacterial Growth and Magnesium Utilization
}

\author{
By M. WEBB \\ Strangeways Research Laboratory, Cambridge
}

(Accepted for publication 9 October 1967)

\begin{abstract}
SUMMARY
The uptake of $\mathrm{Mg}^{2+}$ in $\mathrm{Mg}^{2+}$-limited cultures of the Gram-negative Escherichia coli is rapid and is complete some time before the onset of the stationary phase. In similar cultures of the Gram-positive Bacillus megaterium and $B$. subtilis $\mathrm{F} 3$ growth and $\mathrm{Mg}^{2+}$ assimilation cease at the same time and when only part of the available $\mathrm{Mg}^{2+}$ has been utilized; thereafter efflux of the cation may occur. In these cultures, as in dilute suspensions of the bacilli in a $\mathrm{Mg}^{2+}$-deficient medium, viability is maintained in a high percentage of the organisms, and growth occurs on the addition of $\mathrm{Mg}^{2+}$, even if this is delayed for $20 \mathrm{hr}$. The minimum growth-requirement for $\mathrm{Mg}^{2+}$ varies for different Gram-positive bacilli and is particularly low for Bacillus subtilis var. niger. The response of this organism to $\mathrm{Mg}^{2+}$ is unaffected by $\mathrm{Mn}^{2+}$. The $\mathrm{Mg}^{2+}$ requirements of $B$. megaterium and $B$. subtilis $\mathrm{F} 3$, however, are reduced by $25 \mu \mathrm{M} \mathrm{Mn}{ }^{2+}$. Although this concentration of $\mathrm{Mn}^{2+}$ is unable to support growth of these bacilli in the complete absence of $\mathrm{Mg}^{2+}$, it appears to stimulate the uptake of the latter cation from dilute solutions. $\mathrm{Mn}^{2+}$ also is assimilated during growth by both Gram-positive and Gram-negative bacteria, although less efficiently than $\mathrm{Mg}^{2+}$, and is incorporated into the ribosomes.
\end{abstract}

\section{INTRODUCTION}

In a recent paper Tempest, Dicks \& Meers (1967) have reported that the magnesium contents of $\mathrm{Mg}^{2+}$-limited Bacillus subtilis var. niger and Aerobacter aerogenes, when grown in continuous culture at corresponding rates, are not significantly different, and that, at low dilution rates, the uptake of the cation by both of these organisms is almost complete. Tempest et al. (1967) conclude from these findings and batch culture experiments with $B$. subtilis var. niger and $B$. megaterium that the interpretation of previous observations (Webb, 1966) on the differences in the abilities of certain Gram-positive bacilli and Gram-negative bacteria in batch culture to concentrate $\mathrm{Mg}^{2+}$ from simple chemically defined media is incorrect. The authors suggest that any variation in the response of these organisms to low concentrations of $\mathrm{Mg}^{2+}$ must be due to physiological factors other than differences in assimilation, and in this connexion infer the importance of a differential effect of $\mathrm{Mg}^{2+}$ deficiency on the death rates of Gram-positive and Gram-negative organisms in aqueous environments. This hypothesis, which presumably would require the more efficient retention of $\mathbf{M g}^{2+}$ by the Gram-negative bacteria, is supported by the difference that has been observed in the relative binding affinities of $A$. aerogenes and $B$. subtilis var. niger for $\mathrm{Mg}^{2+}$ (Tempest et al. 1967).

Several other explanations for the discrepancies between the work of Webb (1966) 
and of Tempest et al. (1967), however, are possible. First, the results that are described in the two papers refer to cultures in different phases of growth, i.e. the stationary and logarithmic phases respectively. The cellular content of $\mathrm{Mg}^{2+}$ is related to that of RNA (Dicks \& Tempest, I966; Tempest, Dicks \& Hunter, 1966), which is known to decrease at the end of exponential growth (e.g. Malmgren \& Hedén, 1947). It is possible therefore that the content per organism of bound $\mathrm{Mg}^{2+}$ is greater in exponentially growing than in stationary populations, and that in the Gram-positive bacilli this excess cation is returned to the medium at the end of the logarithmic phase.

Secondly, the Gram-positive bacilli differ amongst themselves with regard to the $\mathrm{Mg}^{2+}$ concentration that is required to initiate growth (Webb, 1966). It is possible, therefore, that Bacillus subtilis var. niger may assimilate $\mathrm{Mg}^{2+}$ more efficiently and thus exhibit a lower requirement for the cation than the organisms that have been studied hitherto.

Thirdly, the growth medium of Tempest et al. (1967) contains 'trace amounts' of other bivalent cations $\left(\mathrm{Cu}^{2+}, \mathrm{Mn}^{2+}, \mathrm{Zn}^{2+}\right)$ and of the molybdate anion. Any of these ions, which are not included in Webb's (1966) medium, may influence the utilization of $\mathrm{Mg}^{2+}$.

The present paper is concerned with an investigation of these possibilities. It is shown that, in contrast to the Gram-negative Escherichia coli, efflux of cellular $\mathrm{Mg}^{2+}$ does occur when cultures of the Gram-positive bacilli enter the stationary phase, but in Webb's (1966) $\mathrm{Mg}^{2+}$-limited medium the assimilation of the cation is incomplete even during the logarithmic growth phase. The $\mathrm{Mg}^{2+}$ requirements of these organisms, however, are reduced considerably by the presence of $\mathrm{Mn}^{2+}$ at the concentration $(25 \mu \mathrm{M})$ that is included in the medium of Tempest et al. (1967). Under these conditions growth occurs at low concentrations of $\mathrm{Mg}^{2+}$ and the uptake of this cation is proportionately greater. In the absence of $\mathrm{Mn}^{2+}$ and other trace metals, the response of Bacillus subtilis var. niger to $\mathrm{Mg}^{2+}$ is similar to that of other Gram-positive bacilli, although the concentration of the cation that is necessary to initiate growth is much lower.

\section{METHODS}

Organisms. The sources and conditions of maintenance of Bacillus megaterium (KM), B. subtilis (F 3), B. mesentericus and Escherichia coli have been given previously (Webb, 1966). B. subtilis var. niger was obtained from Dr D. W. Tempest and was maintained by monthly subculture on Evans peptone-agar slopes containing $0.2 \%$ glucose.

Growth conditions. Cultures were grown in shaken flasks at $37^{\circ}$ in either $\mathbf{P}$ medium (Webb, 1966) or T medium (Tempest et al. 1967). These solutions were supplemented with $\mathrm{Mg}^{2+}$ and other ions as stated in the text and were sterilized by filtration through sintered glass filters. Inocula for the experimental series were taken from organisms that had been subcultured at least three times in the appropriate defined medium. Growth was measured turbidimetrically as described previously (Webb, I966).

Viable counts were made by plating on to Evans peptone $(2 \%, \mathrm{w} / \mathrm{v})$-glucose $(0.2 \%, w / v)$-agar $(2 \%, w / v)$.

Isolation of ribosomes from cells grown in the presence of ${ }^{54} \mathrm{Mn}^{2+}$. Cultures were grown in P medium (500 ml.) supplemented with ${ }^{54} \mathrm{Mn}^{2+}$ (I0 $\mu \mathrm{C}$; The Radiochemical Centre, Amersham, Bucks.) and $\mathrm{Mg}^{2+}$ as indicated in Table 2. After being harvested and washed 3 times with solution $\mathrm{L}$ (0.0I M-tris buffer, $\mathrm{pH} 7.4,0.06 \mathrm{M}-\mathrm{KCl}$ and 
$0.014 \mathrm{M}-\left(\mathrm{CH}_{3} \mathrm{COO}\right)_{2} \mathrm{Mg}$ ), the organisms were resuspended in the same solution ( $15 \mathrm{ml}$.) and treated at $0^{\circ}$ with ultrasonic vibrations in an M.S.E. machine $(4 \times 30 \mathrm{sec}$. at I. $5 \mathrm{~A}$ with $30 \mathrm{sec}$. intervals of rest). This method, which yielded ribosomal preparations that were comparable with those obtained from organisms that were crushed in the French press, was used in preference to the more conventional procedures for the disintegration of the labelled organisms. The homogenates were treated with DNAse (I $\mu \mathrm{g} . / \mathrm{ml}$.; Sigma Chemical Co., London; RNAse-free) for $5 \mathrm{~min}$. at room temperature and then centrifuged at $4^{\circ}$ for Io min. at $18,000 \mathrm{~g}$. The supernatant fractions were centrifuged for 70-90 min. at I 14,000 $\mathrm{g}$ (Spinco Model L centrifuge, no. 40 rotor) and $0^{\circ}$. The crude ribosomal pellets were dissolved in mixture $\mathrm{L}$, the solutions centrifuged

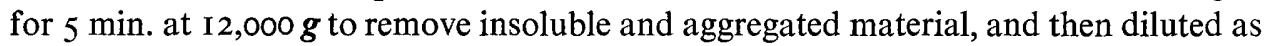
necessary to contain $0.9-\mathrm{I} \cdot 0 \mathrm{mg}$. RNA $/ \mathrm{ml}$. Portions $(0.2 \mathrm{ml}$.) of these solutions were layered on to continuous gradients of $10 \%-25 \%(\mathrm{w} / \mathrm{v})$ sucrose in mixture $\mathrm{L}$, and centrifuged for $100 \mathrm{~min}$. at $\mathrm{I} 25,000 \mathrm{~g}$ and $4^{\circ}$ in the no. 39 rotor of the Spinco ultracentrifuge. Three gradients were run with each crude preparation. After centrifugation the bottom of each tube was pierced with a no. 16 hypodermic needle, and a series of 20-drop fractions was collected. These fractions were diluted with solution L ( $1 \cdot 0 \mathrm{ml}$.) and the main ribosomal components located by measurement of the $E 260$ values. The appropriate fractions from each series were combined and the ribosomes were recovered by centrifugation for $90 \mathrm{~min}$. at I I $4,000 \mathrm{~g}$. The particle dry weight was calculated from the decrease in the $E 260$ value on centrifugation of each solution according to Imsande \& Caston (I966).

Measurement of radioactivity. The ribosomal or cell pellets were dissolved in $98 \%$ $(\mathrm{w} / \mathrm{v})$ formic acid $\left(0.5 \mathrm{ml}\right.$.) at $60^{\circ}$ before assay. Radioactivity was measured as described by Daniel, Dingle, Webb \& Heath (1963).

Analytical methods. $\mathrm{Mg}^{2+}$ and $\mathrm{Mn}^{2+}$ were determined in culture supernatants by atomic absorption, the former by direct analysis in the presence of $\mathrm{La}^{3+}$ (Webb, I966) and the latter by scale expansion in conjunction with the Perkin Elmer Recorder Readout accessory.

\section{RESULTS}

\section{Utilization of $\mathrm{Mg}^{2+}$ in $\mathrm{Mg}^{2+}$-limited cultures of Escherichia coli, Bacillus megaterium and B. subtilis $F 3$}

Variation of the $\mathrm{Mg}^{2+}$ content of $\mathbf{P}$ medium over the range $0 \cdot 25-2 \cdot 0 \mu \mathrm{g} \mathrm{Mg}^{2+} / \mathrm{ml}$. influenced both the rate and duration of the logarithmic growth phase of Escherichia coli, but had little effect on the length of the initial lag (Table I). In $\mathrm{Mg}^{2+}$-limited cultures of this organism the uptake of $\mathrm{Mg}^{2+}$ occurred rapidly, and the concentration of the cation in the medium was reduced to zero, usually within $2 \frac{1}{2}-3 \mathrm{hr}$ of the end of the lag phase (Fig. I). After the complete utilization of the available $\mathrm{Mg}^{2+}$, which correlated approximately with the transition from logarithmic growth to the phase of decreasing multiplication rate, the cell density increased by at least $33 \%$ in the absence of the exogenous cation. In cultures that contained initially 0.2 and $0.5 \mu \mathrm{g} . \mathrm{Mg}^{2+} / \mathrm{ml}$. the cell densities reached maximum values and then decreased by about $32 \%$ and $21 \%$ respectively between 8 and $20 \mathrm{hr} . \mathrm{Mg}^{2+}$ ions were not liberated from the cells during this period. At higher levels of $\mathrm{Mg}^{2+}\left(\mathrm{I}^{\cdot} 5^{-4} \cdot \mathrm{O} \mu \mathrm{g}\right.$. $\mathrm{Mg}^{2+} / \mathrm{ml}$.) some slight efflux of the cation occurred between 6 and 8 hr (Table I).

In agreement with previous findings (Webb, I966), the growth of Bacillus mega- 
terium and $B$. subtilis $\mathrm{F} 3$ in P medium was limited to a greater extent by low concentrations of $\mathrm{Mg}^{2+}$ than was that of Escherichia coli (Fig. I). Throughout the period of incubation of cultures of the Gram-positive bacilli the utilization of $\mathrm{Mg}^{2+}$ from media with initial concentrations of $0.5,0.9$ and $\mathrm{r} \cdot 2 \mu \mathrm{g}$. $\mathrm{Mg}^{2+} / \mathrm{ml}$. was not quantitative. In

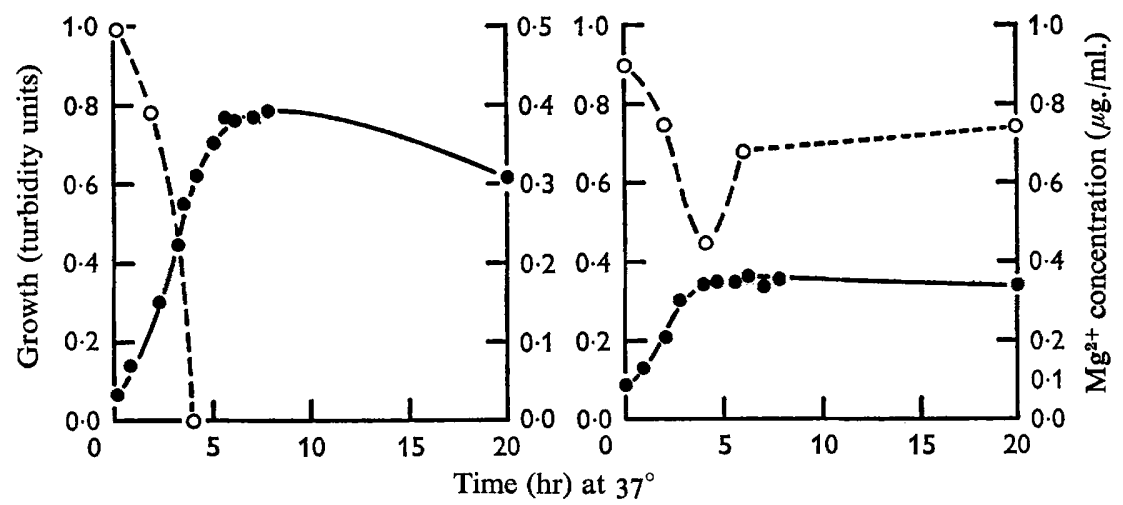

Fig. I. Growth (- $(-)$ and magnesium utilization $\left(O-O^{-}\right)$in cultures of Escherichia coli with $0.5 \mu \mathrm{g}$. $\mathrm{Mg}^{2+} / \mathrm{ml}$., and in cultures of Bacillus megaterium with $0.9 \mu \mathrm{g} . \mathrm{Mg}^{2+} / \mathrm{ml}$. in $\mathrm{P}$ medium.

\section{Table I. Magnesium utilization in $\mathbf{M g}^{2+}$-limited cultures of Escherichia coli}

The experimental cultures were grown with shaking in $P$ medium ( $15 \mathrm{ml}$.) supplemented with different amounts of $\mathrm{Mg}^{2+}$ in conical flasks $(50 \mathrm{ml}$.) that were fitted with side arms for turbidimetric measurements. At the intervals shown, portions $(3.0 \mathrm{ml}$.) of the cultures were removed aseptically, centrifuged and the supernatant fractions analysed for $\mathbf{M g}^{2+}$. The inocula $\left(0.3 \mathrm{ml}\right.$.) were taken from a $16 \mathrm{hr}$ culture in $\mathrm{P}$ medium with $2 \mu \mathrm{g}$. $\mathrm{Mg}^{2+} / \mathrm{ml}$.

\begin{tabular}{|c|c|c|c|c|c|c|}
\hline \multirow{3}{*}{$\begin{array}{c}\text { Time } \\
\text { (hr) at } \\
37^{\circ}\end{array}$} & \multicolumn{6}{|c|}{$\mathrm{Mg}^{2+}$ concentration $(\mu \mathrm{g} . / \mathrm{ml})}$. \\
\hline & \multicolumn{5}{|c|}{$\mu \mathrm{g}$. dry wt organisms $/ \mathrm{ml}$. } & \\
\hline & 0.2 & 0.5 & $I \cdot 0$ & I 5 & $2 \cdot 0$ & $4 \cdot 0$ \\
\hline $1 \cdot 5$ & I9 & 23 & 26 & 26 & 24 & 32 \\
\hline $2 \cdot 0$ & 40 & 33 & 33 & 37 & 36 & $4 \mathrm{I}$ \\
\hline $3 \cdot 0$ & 85 & 94 & 79 & 78 & 90 & 90 \\
\hline $3 \cdot 75$ & I 22 & 154 & I 54 & 156 & 159 & 163 \\
\hline $4 \cdot 0$ & 137 & 188 & 204 & 206 & 214 & 217 \\
\hline 5.0 & 169 & 263 & 379 & 409 & 430 & 440 \\
\hline $6 \cdot 0$ & 180 & 302 & 459 & 539 & 595 & 714 \\
\hline $7 \cdot 0$ & 199 & 344 & 514 & 616 & 775 & 794 \\
\hline $8 \cdot 0$ & 197 & 359 & 533 & 735 & 760 & 950 \\
\hline \multicolumn{7}{|c|}{ Residual $\mathrm{Mg}^{2+}(\mu \mathrm{g} . / \mathrm{ml})}$. \\
\hline 2.0 & 0.18 & 0.50 & 0.87 & $I \cdot 32$ & $\mathrm{I} \cdot 79$ & $3 \cdot 42$ \\
\hline 4.0 & 0.04 & 0.03 & 0.19 & 0.66 & 1.02 & 2.66 \\
\hline $6 \cdot 0$ & 0.02 & $0.0 \mathrm{I}$ & 0.03 & 0.03 & 0.01 & 0.03 \\
\hline $8 \cdot 0$ & 0.00 & 0.00 & 0.00 & 0.01 & 0.04 & 0.10 \\
\hline
\end{tabular}

each culture, the cation content of the medium decreased to a minimum at the onset of the stationary phase and then increased. At the low medium concentrations of $\mathrm{Mg}^{2+}$ the liberation of the cation coincided with lysis, as shown by the decrease in turbidity of the cultures after $3 \mathrm{hr}$. At the higher levels of $\mathrm{Mg}^{2+}$, however, turbidity remained essentially constant between 8 and $20 \mathrm{hr}$. 


\section{$\mathrm{Mg}^{2+}$ requirements of Bacillus subtilis var. niger}

In cultures of Bacillus subtilis var. niger in P medium the lag in the growth response to increasing concentrations of $\mathrm{Mg}^{2+}$ was much shorter than with other Gram-positive bacilli that have been studied previously in batch culture (Webb, 1966). Growth began at about $0 \cdot 15-0 \cdot 2 \mu \mathrm{g}$. $\mathrm{Mg}^{2+} / \mathrm{ml}$., and then increased rapidly with the concentration of the cation, whilst in cultures that contained low levels of $\mathrm{Mg}^{2+}$ the utilization of the cation was almost complete.

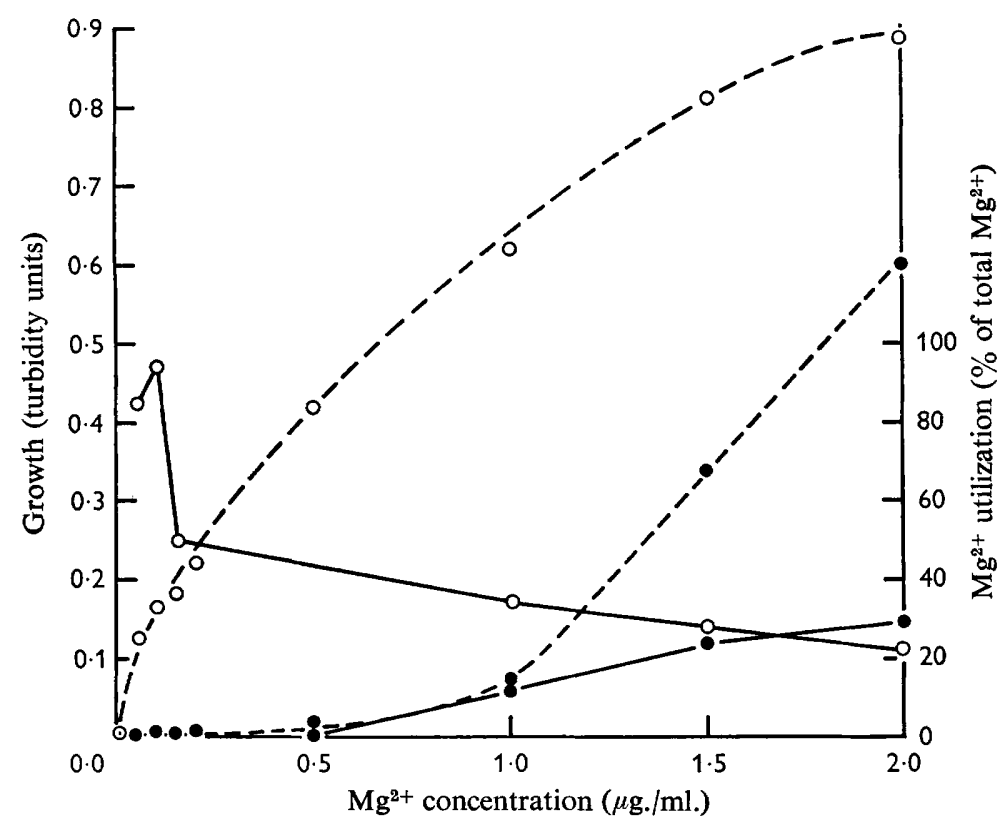

Fig. 2. Growth (---), and $\mathrm{Mg}^{2+}$ utilization (-) as functions of $\mathbf{M g}^{2+}$ concentration in cultures of Bacillus subtilis $\mathrm{F} 3$, in T medium $(\mathrm{O})$ and $\mathrm{P}$ medium $(\bullet)$.

Influence of other ions on the utilization of $\mathrm{Mg}^{2+}$ by Gram-positive bacilli. In the medium of Tempest et al. (1967), both the growth response to $\mathrm{Mg}^{2+}$ and the utilization of the cation by Bacillus subtilis F 3, B. megaterium and B. mesentericus were different from those in $\mathrm{P}$ medium. Thus in T medium the growth lag at low levels of $\mathrm{Mg}^{2+}$ was eliminated and the utilization of the cation at concentrations below $0 . \mathrm{I} \mu \mathrm{g}$. $\mathrm{Mg}^{2+} / \mathrm{ml}$. was almost complete (Fig. 2). Under these conditions there was little difference, for example, in the response of B. subtilis F 3 (Fig. 2) and of B. subtilis var. niger.

As the major components of $P$ and $T$ media were similar, these observations indicated that the $\mathrm{Mg}^{2+}$-requirements of at least certain Gram-positive bacilli were modified by the additional trace metals $\left(\mathrm{Mn}^{2+}, \mathrm{Cu}^{2+}, \mathrm{Zn}^{2+}\right.$ and $\left.\mathrm{MoO}_{4}{ }^{2-}\right)$ of $\mathrm{T}$ medium. In $\mathrm{P}$ medium the $\mathrm{Mg}^{2+}$, requirements for growth of Bacillus subtilis $\mathrm{F} 3$ and B. megaterium were reduced greatly by $\mathrm{Mn}^{2+}$, but were increased by $\mathrm{Cu}^{2+} \mathrm{Zn}_{4}{ }^{2+}$ and $\mathrm{MoO}_{4}{ }^{2-}$ when these ions were added separately in the amounts present in T medium (Fig. 3). Although $\mathrm{Mn}^{2+}(25 \mu \mathrm{M})$ alone was unable to support the growth of these organisms, it stimulated the uptake of $\mathrm{Mg}^{2+}$ when this ion was present in low concentration. With 
B. subtilis var. niger the utilization of $\mathrm{Mg}^{2+}$ was increased slightly by $\mathrm{Mn}^{2+}$, and decreased by $\mathrm{Cu}^{2+}, \mathrm{Zn}^{2+}$ and $\mathrm{MoO}_{4}{ }^{2-}$, although none of these ions had any significant effect on the growth response of this organism to increasing concentrations of $\mathrm{Mg}^{2+}$. The latter finding was confirmed by a study of the response of $B$. subtilis var. niger to $\mathrm{Mg}^{2+}$ in $T$ medium from which the various trace metal components were omitted separately. When $\mathrm{Mn}^{2+}, \mathrm{Cu}^{2+}$ and $\mathrm{MoO}_{4}{ }^{2-}$ were omitted together, however, growth did not occur at $\mathrm{Mg}^{2+}$ concentrations lower than $0.15 \mu \mathrm{g}$. $\mathrm{Mg}^{2+} / \mathrm{ml}$., and at $2 \mu \mathrm{g} . \mathrm{Mg}^{2+} / \mathrm{ml}$. the cell

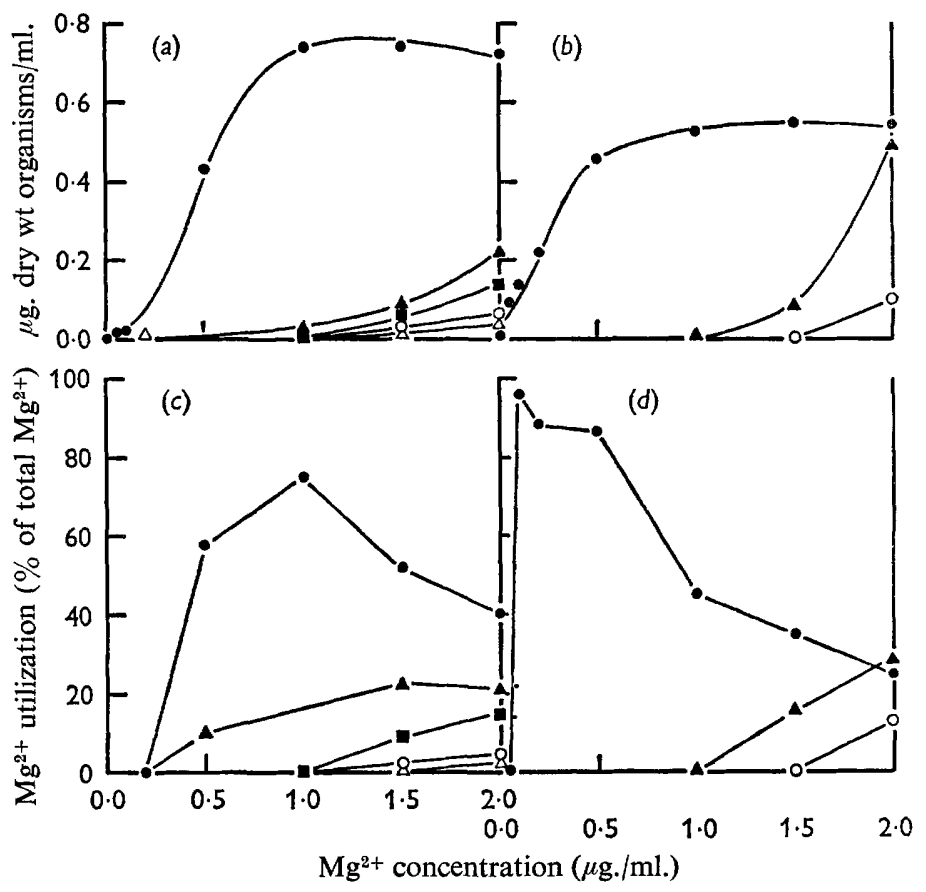

Fig. 3. Influence of other ions on growth (upper figures) and $\mathrm{Mg}^{2+}$ utilization (lower figures) in $\mathrm{Mg}^{2+-}$-limited cultures of Bacillus megaterium $(a, c)$ and Bacillus subtilis $\mathrm{F} 3(b, d)$. Additions to $\mathrm{P}$ medium were as follows: none $(\Delta), 25 \mu \mathrm{M}-\mathrm{Mn}^{2+}(\bullet), 5 \mu \mathrm{M}-\mathrm{MoO}_{4}{ }^{2-}(\boldsymbol{\square})$, Io $\mu \mathrm{M}-$ $\mathrm{Zn}^{2+}(0), 5 \mu \mathrm{M}-\mathrm{Cu}^{2+}(\mathrm{O})$.

density in fully grown cultures was $25 \%$ less than in the complete medium. In some experiments with this organism in the absence of $\mathrm{Cu}^{2+}, \mathrm{Zn}^{2+}$ and $\mathrm{MoO}_{4}{ }^{2-}, \mathrm{Mn}^{2+}$ $(25 \mu \mathrm{M})$ antagonized the uptake of $\mathrm{Mg}^{2+}$ at concentrations of less than $0.5 \mu \mathrm{g} . / \mathrm{ml}$. and, at the lowest levels of $\mathrm{Mg}^{2+}$, caused the liberation of this cation from the cells of the noculum. This antagonism, however, was not consistently reproducible. At higher concentrations $\left(\mathrm{r} \cdot 0-2 \cdot 0 \mu \mathrm{g} . / \mathrm{ml}\right.$.) of $\mathrm{Mg}^{2+}, \mathrm{Mn}^{2+}$ acted synergistically, the increase in dry wt organisms $/ \mathrm{ml}$. under these conditions being $95-98 \%$ of that in corresponding cultures in the complete medium, and the uptake of $\mathrm{Mg}^{2+}$ about $35 \%$ greater.

Utilization of $\mathrm{Mn}^{2+}$ by Escherichia coli, Bacillus megaterium and B. subtilis var. niger. Analysis of cell-free supernatant fractions from the above experiments established that, irrespective of the $\mathrm{Mg}^{2+}$ concentration, only a small fraction of the available $\mathrm{Mn}^{2+}$ was assimilated by each of the three organisms. As the decrease in the content of this cation in the media was too low to be determined accurately by atomic absorption, uptake was measured with ${ }^{54} \mathrm{Mn}^{2+}$ as tracer. 
In Bacillus megaterium and B. subtilis var. niger, as in Escherichia coli, $\mathrm{Mn}^{2+}$ was taken up during growth and incorporated into the ribosomes (Table 2). It is probable that in the three organisms the $\mathrm{Mn}^{2+}$ contents of the native, intracellular ribosomes were higher than those found for the isolated particles, since these were prepared in the presence of a relatively high concentration (I4 mM) of $\mathrm{Mg}^{2+}$ to prevent dissociation to the $50 \mathrm{~S}$ and $30 \mathrm{~S}$ sub-units. Although the binding affinity of bacterial (E. coli) ribosomes for $\mathrm{Mn}^{2+}$ is about 3 times that of $\mathrm{Mg}^{2+}$ (Sheard et al. 1967) it is to be expected that some displacement of the former cation by the latter would occur under the conditions of the present experiments. In culture, $\mathrm{Mg}^{2+}$ antagonized the uptake of $\mathrm{Mn}^{2+}$. Thus, as shown in Table 2, a Io-fold increase in the $\mathrm{Mg}^{2+}$ concentration of the medium depressed the $\mathrm{Mn}^{2+}$ content of the whole cells and isolated ribosomes of E. coli by $87 \%$ and $80 \%$ respectively. In this connexion it is interesting that the $\mathrm{Mn}^{2+}$

\section{Table 2. Incorporation of ${ }^{54} \mathrm{Mn}^{2+}$ by Escherichia coli, Bacillus megaterium and Bacillus subtilis var. niger}

The cultures were grown with aeration at $37^{\circ}$ in $\mathrm{P}$ medium (500 ml.) supplemented with I2.5 $\mu$ moles $\mathrm{Mn}^{2+}$ (10 $\mu \mathrm{C}^{54} \mathrm{Mn}^{2+}$ ) and $\mathrm{Mg}^{2+}$ as shown, from inocula (5 ml.) that contained medium concentrations of $\mathrm{Mg}^{2+}$ of $\mathrm{I} \mu \mathrm{g}$. $/ \mathrm{ml}$. (E. coli), $2 \mu \mathrm{g} . / \mathrm{ml}$. (B. subtilis var. niger) and $5 \mu \mathrm{g} . / \mathrm{ml}$. (B. megaterium). Growth was followed turbidimetrically to enable the two cultures of $E$. coli and of the Gram-positive bacilli to be harvested in the logarithmic phase at approximately the same dry wt organisms $/ \mathrm{ml}$. The procedures for the isolation of ribosomes and the determination of $\mathrm{Mn}^{2+}$ were as described in the Materials and Methods section.

\begin{tabular}{|c|c|c|c|c|c|}
\hline \multirow[b]{2}{*}{ Organism } & \multirow{2}{*}{$\begin{array}{c}\mathrm{Mg}^{2+} \text { content } \\
\text { of culture } \\
\text { medium } \\
(\mu \mathrm{g} . / \mathrm{ml} .)\end{array}$} & \multirow{2}{*}{$\begin{array}{c}\text { Yield } \\
\text { (mg. dry wt } \\
\text { organisms) }\end{array}$} & \multirow{2}{*}{$\begin{array}{c}\text { Total } \mathrm{Mn}^{2+} \\
\text { incorporated } \\
\text { by cells } \\
\text { ( } \mu \text { moles })\end{array}$} & \multicolumn{2}{|c|}{$\begin{array}{l}\mathrm{Mn}^{2+} \text { content }(\mathrm{m} \mu- \\
\text { moles/mg. dry } \mathrm{wt})\end{array}$} \\
\hline & & & & Cells & Ribosomes \\
\hline coli & 0.5 & $94 \cdot 6$ & 0.123 & $I \cdot 30$ & $\mathrm{I} \cdot 32$ \\
\hline coli & $5 \cdot 0$ & $91 \cdot 7$ & 0.016 & $0 \cdot 17$ & $0 \cdot 27$ \\
\hline $\begin{array}{l}\text { B. subtilis var. } \\
\text { niger }\end{array}$ & $1 \cdot 0$ & $134 \cdot 7$ & $0 \cdot 122$ & $0.8 \mathrm{I}$ & $1 \cdot 04$ \\
\hline B. megaterium & $2 \cdot 0$ & $148 \cdot 0$ & 0.264 & $\mathrm{I} \cdot 78$ & $\mathrm{I} \cdot 8 \mathrm{I}$ \\
\hline
\end{tabular}

contents of $B$. megaterium cells and ribosomes were approximately double those of $B$. subtilis var. niger, although the $\mathrm{Mg}^{2+}$ concentration in the culture of the former was twice that of the latter. It seems therefore that $B$. megaterium may have a lower affinity for $\mathrm{Mg}^{2+}$ than $B$. subtilis var. niger, but a higher affinity for $\mathrm{Mn}^{2+}$.

\section{Loss of viability in Gram-positive bacilli in the absence of $\mathrm{Mg}^{2+}$}

Although Bacillus megaterium, B. subtilis $\mathrm{F} 3$ and B. subtilis var. niger failed to grow in either $\mathbf{P}$ or $\mathrm{T}$ medium in the absence of $\mathrm{Mg}^{2+}$, viability was maintained. With both $B$. subtilis $\mathrm{F} 3$ and $B$. megaterium, the viable count fell by about $45 \%$ during $20 \mathrm{hr}$ at $37^{\circ}$, a $25 \%$ decrease being observed within the first $3.5 \mathrm{hr}$ of incubation. The deathrates of these organisms in the $\mathrm{Mg}^{2+}$-deficient $\mathbf{P}$ medium were little affected by $\mathrm{Mn}^{2+}$, $\mathrm{Cu}^{2+}$ and $\mathrm{MoO}_{4}{ }^{2-}$, but were increased by $\mathrm{Zn}^{2+}$ (IO $\mu \mathrm{M}$ ), in some experiments by as much as $90-95 \%$ in $6 \mathrm{hr}$. Even in the presence of $\mathrm{Zn}^{2+}$ some cells survived for $20 \mathrm{hr}$ and were capable of growth when the medium was supplemented with $\mathrm{Mg}^{2+}(\mathrm{I} 0 \mu \mathrm{g} . / \mathrm{ml}$.).

In cultures of Bacillus subtilis F 3 in P medium with $0.5 \mu \mathrm{g} . \mathrm{Mg}^{2+} / \mathrm{ml}$., as in those of B. megaterium, there was no stable stationary state, but a decrease in cell density after $6 \mathrm{hr}$ (Fig. 4). This decrease in density was exaggerated by the turbidimetric measurements since once the growth maximum was attained, the cells tended to 
agglutinate. Agglutination was correlated with a change in morphology from Grampositive rods to Gram-negative filaments of uneven thickness, the majority of which were swollen at one or both ends. Sporulation did not occur. With most Grampositive bacilli, the formation of filaments in response to $\mathrm{Mg}^{2+}$ deficiency occurs in complex media, but not in simple nutrient solutions unless these are supplemented with amino acids (Webb, I95 $b$ ). This atypical behaviour of $B$. subtilis $\mathrm{F} 3$, however, has been described previously by Grunau (1958).

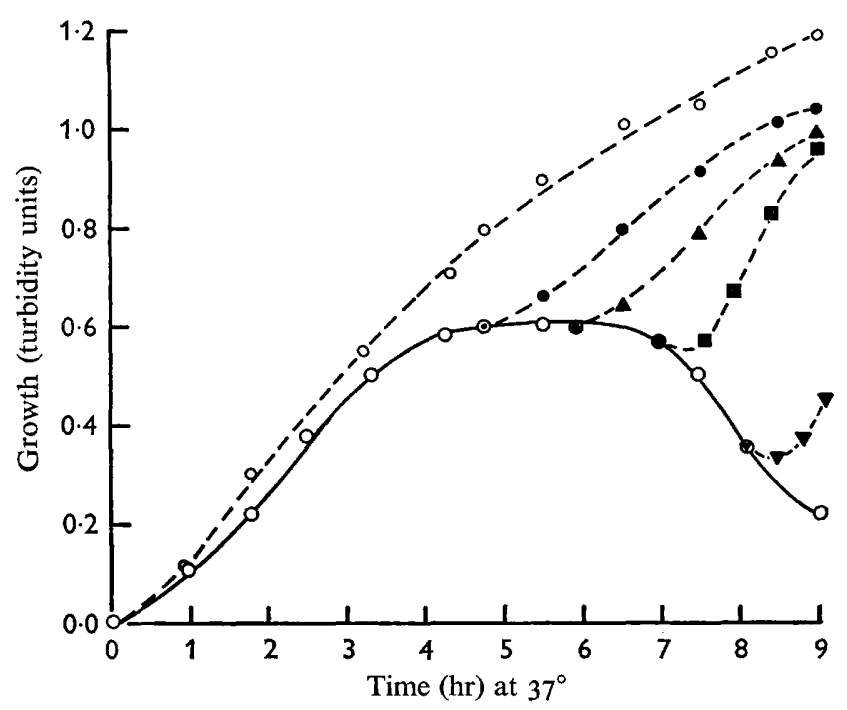

Fig. 4. Response of $\mathrm{Mg}^{2+}$-limited cultures of Bacillus subtilis $\mathrm{F} 3$ to $\mathrm{Mg}^{2+}$. The parent culture $(\mathrm{O}-\mathrm{O})$ was grown with shaking in $\mathrm{P}$ medium with limited $\mathrm{Mg}^{2+}\left(0.5 \mu \mathrm{g} . / \mathrm{ml}\right.$.) at $37^{\circ}$ under the conditions described in Table I. Portions of this culture were supplemented with

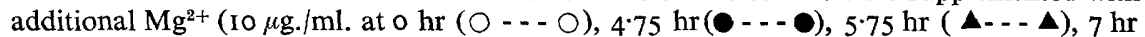

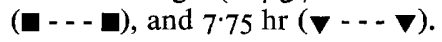

On the addition of $\mathrm{Mg}^{2+}$ (Io $\mu \mathrm{g}$. $/ \mathrm{ml}$.) to a $\mathrm{Mg}^{2+}-$ limited culture of Bacillus subtilis F 3 growth recommenced with little or no lag with the production of a new population of morphologically normal, Gram-positive cells. An interesting and unexpected feature of these results (Fig. 4) was that the rate of multiplication in the second growth phase increased the later the $\mathrm{Mg}^{2+}$ was added, and was greatest during the period of the decrease in turbidity of the parent culture. It appears therefore that the $\mathrm{Mg}^{2+}$ requirements of cells which survive during the period of degeneration in $\mathrm{Mg}^{2+}$-deficient cultures of $B$. subtilis $\mathrm{F} 3$, and which resume growth on the addition of $\mathrm{Mg}^{2+}$, are reduced by the presence of products from other autolysed cells. Certain amino acids, for example, are known to reduce the $\mathrm{Mg}^{2+}$ requirements of various Gram-positive bacilli in simple media (Webb, 195 $b$, 1966).

\section{Effect of other ions on the leakage of $\mathrm{Mg}^{2+}$ from Gram-positive bacilli}

Previously (Webb, I966) it was reported that when Gram-positive bacilli are transferred to a $\mathrm{Mg}^{2+}$-deficient medium leakage of $\mathrm{Mg}^{2+}$ occurs progressively with time and often precedes a decrease in cell density. A number of observations suggest that a bivalent cation, usually considered to be either $\mathrm{Mg}^{2+}$ or $\mathrm{Ca}^{2+}$, is necessary to maintain 
the integrity of the bacterial cell wall, cell membrane or permeability barriers (e.g. Strange, 1964: Gray \& Wilkinson, 1965: Hamilton-Miller, 1966; Goldman, 1966). The trace amounts of $\mathrm{Cu}^{2+}$ and $\mathrm{Mn}^{2+}$ in the medium of Tempest et al. (I967) also appeared to stabilize Gram-positive cells and, in the absence of exogenous $\mathrm{Mg}^{2+}$, prevented both the leakage of this cation and the decrease in cell density. The loss of $\mathrm{Mg}^{2+}$ which occurred, for example, when cells from the exponential phase of a culture of Bacillus subtilis in P medium with $2 \mu \mathrm{g}$. $\mathrm{Mg}^{2+} / \mathrm{ml}$. were transferred to fresh medium without $\mathrm{Mg}^{2+}$ was prevented completely by $\mathrm{Cu}^{2+}(5 \mu \mathrm{M})$ and reduced by $85 \%$ in the presence of $\mathrm{Mn}^{2+}(25 \mu \mathrm{M})$.

\section{DISCUSSION}

The present results confirm and extend those reported previously (Webb, I966) on the difference in the abilities of certain Gram-positive and Gram-negative bacteria in batch culture to concentrate $\mathrm{Mg}^{2+}$ from a simple chemically defined medium. In $\mathrm{Mg}^{2+}$-limited cultures of the Gram-negative Escherichia coli for example, the utilization of the cation is rapid and is complete some time before the stationary phase is reached. In contrast, in similar cultures of the Gram-positive Bacillus megaterium and B. subtilis $\mathrm{F} 3$ only part of the available $\mathrm{Mg}^{2+}$ is utilized; growth and $\mathrm{Mg}^{2+}$ assimilation cease at the same time, and thereafter efflux of the cation may occur. This efflux of $\mathrm{Mg}^{2+}$ may be either accompanied or followed by some cell lysis. In such stationary cultures of the Gram-positive bacilli, as in dilute cell suspensions in $\mathrm{Mg}^{2+}$-deficient media, some cells remain viable and are able to grow on the addition of $\mathrm{Mg}^{2+}$, even if this is delayed for $20 \mathrm{hr}$. Thus contrary to the suggestion of Tempest et al. (I967), loss of viability of the Gram-positive bacilli cannot account for the differences in the growth response of these and Gram-negative bacteria to low concentrations of $\mathrm{Mg}^{2+}$.

The concentration of $\mathrm{Mg}^{2+}$ that is necessary to initiate growth of various Grampositive bacilli varies with the species (Webb, I949, I966), and appears to be extremely small for Bacillus subtilis var. niger, the organism that has been used in most of the comparative studies of Tempest et al. (1967). This strain of B. subtilis is able to grow in the $\mathbf{P}$ medium, and to assimilate $\mathrm{Mg}^{2+}$, at concentrations of the cation that are inadequate for a number of other bacilli.

In cultures of certain of the Gram-positive bacilli the $\mathrm{Mg}^{2+}$ requirements for growth are reduced by $\mathrm{Mn}^{2+}(25 \mu \mathrm{M})$. The synergistic action of $\mathrm{Mn}^{2+}$ is in agreement with previous observations (Webb, I95I $a$ ) on the partial ability of this cation to substitute for $\mathrm{Mg}^{2+}$ in the nutrition of these organisms. The present results, however, show that in the complete absence of $\mathrm{Mg}^{2+}$ this limited concentration of $\mathrm{Mn}^{2+}$ is unable to support growth of either the Gram-negative Escherichia coli or a number of Grampositive bacilli, and suggest that either there is some fundamental reaction that has absolute specificity for the former cation, or the transport of $\mathrm{Mn}^{2+}$ is energy-dependent and is activated by $\mathrm{Mg}^{2+}$. Assimilation of $\mathrm{Mn}^{2+}$ is much less efficient than is that of $\mathrm{Mg}^{2+}$, and, at least in $E$. coli, is decreased by increased concentrations of the latter cation. It seems therefore that the relationship between the utilization of these two ions may be synergistic or antagonistic according to their relative concentrations.

It is significant that in the presence of low levels of $\mathrm{Mg}^{2+}, \mathrm{Mn}^{2+}$ is taken up by bacterial cells and incorporated into the ribosomes (Table 2), since, chemically, the inhibition of protein synthesis is the main result of $\mathrm{Mg}^{2+}$ deficiency, particularly in Gram-positive bacilli (Webb, 1953). Kennell \& Kotoulas (1967) have shown that 
$\mathrm{Mn}^{2+}$ partially protects the ribosomes of Aerobacter aerogenes against degradation due to $\mathrm{Mg}^{2+}$ deficiency, whilst the ability of $\mathrm{Mn}^{2+}$ to exchange rapidly with the bound $\mathrm{Mg}^{2+}$ of isolated ribosomes from $E$. coli has been described by Sheard et al. (1967). Earlier, Tissières, Schlessinger \& Gros (I960) reported that $\mathrm{Mn}^{2+}$ was $50 \%$ as efficient as $\mathrm{Mg}^{2+}$ in the activation of protein synthesis by Escherichia coli ribosomes. It seems therefore that incorporation of $\mathrm{Mn}^{2+}$ into the ribosomes of $\mathrm{Mg}^{2+}$ deficient bacteria would maintain the structure and function of the particles, and also liberate some bound $\mathrm{Mg}^{2+}$, which would thus become available for other processes.

The reduced $\mathrm{Mg}^{2+}$ requirements of a number of Gram-positive bacilli in the medium of Tempest et al. (1967) can be explained by the presence of $\mathrm{Mn}^{2+}$. Individually, the other trace metal components of this medium have little effect on either growth or $\mathrm{Mg}^{2+}$ utilization, although under certain conditions $\mathrm{Cu}^{2+}$ may stabilize the cells and prevent both the efflux of $\mathrm{Mg}^{2+}$ and partial lysis that are liable to occur in the absence of the latter cation. The discrepancies between the results of Tempest et al. (1967) and of Webb (I966) thus seem to be due to the use by the former authors of (a) Bacillus subtilis var. niger, a Gram-positive bacillus that is atypical in its $\mathrm{Mg}^{2+}$ requirements, and $(b)$ a medium that contains $\mathrm{Mn}^{2+}$, which can substitute, at least in part, for $\mathrm{Mg}^{2+}$ in the nutrition of both Gram-positive and Gram-negative bacteria.

The author is indebted to Drs D. W. Tempest and A. R. Peacocke for copies of the manuscripts of their papers before publication, and to Mr G. Payton for his excellent technical assistance.

\section{REFERENCES}

Daniel, M., Dingle, J. T., Webb, M. \& Heath, J. C. (I963). The biological action of cobalt and other metals. I. The effect of cobalt on the morphology and metabolism of rat fibroblasts in vitro. Br. J. exp. Path. 44, I63.

Dicks, J. W. \& TEMPEST, D. W. (1966). The influence of temperature and growth rate on the quantitative relationship between potassium, magnesium and ribonucleic acid of Aerobacter aerogenes growing in a chemostat. J. gen. Microbiol. 45, 547.

Goldman, M. (1966). Stabilization of autolysis in Bacillus cereus T. Nature, Lond. 209, 32 I.

Gray, G. W. \& Wilkinson, S. G. (I965). The action of ethylenediamine tetra-acetic acid on Pseudomonas aeruginosa. J. appl. Bact. 28, 153.

GrunaU, J. A. (1958). Some effects of magnesium deficiency in Bacillus subtilis. Ph.D. thesis, University of Cambridge.

Hamilton-Miller, J. M. T. (I966). Damaging effects of ethylene-diamine-tetra-acetate and penicillins on permeability barriers in Gram-negative bacteria. Biochem. $J$. 100, 675 .

IMSANDE, J. \& CASTON, J. D. (1966). Synthesis of protein with a cell-free system from Bacillus cereus 569. J. molec. Biol. 16, 28.

Kennell, D. \& Kotoulas, A. (1967). Magnesium starvation of Aerobacter aerogenes. I. Changes in nucleic acid composition. J. Bact. 93, 334.

Malmgren, B. \& Hedén, G. C. (I947). Studies on the nucleotide metabolism of bacteria. III. The nucleotide metabolism of the Gram-negative bacteria. IV. The nucleotide metabolism of the Gram-positive bacteria. Acta path. microbiol. scand. 24, 448, 472.

Sheard, B., Miall, S., Peacocke, A. R, Walker, I. O. \& Richards, R. E. (1967). Proton magnetic relaxation studies of the binding of $\mathrm{Mn}^{2+}$ ions to $E$. coli ribosomes. J. molec. Biol. (In the Press.)

STRANGE, R. E. (I964). Effect of magnesium on permeability control in chilled bacteria. Nature, Lond. 203, I304.

Tempest, D. W., Dicks, J. W. \& Hunter, J. R. (I966). The interrelationships between potassium, magnesium and phosphorus in potassium-limited chemostat cultures of Aerobacter aerogenes. $J$. gen. Microbiol. 45, 135 . 
Tempest, D. W., Dicks, J. W., \& MeErs, J. L. (1967). Magnesium-limited growth of Bacillus subtilis, in pure and mixed cultures, in a chemostat. J. gen. Microbiol. 49, I39.

Tissières, A., Schlessinger, D. \& Gros, G. (1960). Amino acid incorporation into proteins by Escherichia coli ribosomes. Proc. natn. Acad. Sci. U.S. 46, 1450.

WEBB, M. (1949). The influence of magnesium on cell division. 3. The effect of magnesium on the growth of bacteria in simple chemically defined media. J. gen. Microbiol. 3, 418.

WEBB, M. (I95I $a$ ). The influence of magnesium on cell division. 4 . The specificity of magnesium. $J$. gen. Microbiol. 5, 480 .

WeBB, M. (I95I $b$ ). The influence of magnesium on cell division. 5. The effect of magnesium on the growth of bacteria in chemically defined media of varying complexity. J. gen. Microbiol. $\mathbf{5}, 485$.

WeBb, M. (1953). Effects of magnesium on cellular division in bacteria. Science, N.Y. 118, 607.

WEBB, M. (1966). The utilization of magnesium by certain Gram-positive and Gram-negative bacteria. J. gen. Microbiol. 43, 401 . 